\title{
The Source and Origin of the Mesozoic Kimberlites in South Australia.
}

\author{
John Foden $^{1}$, Ralf Tappert ${ }^{1}$ and Kevin Wills ${ }^{2}$ \\ 1. Geology and Geophysics, University of Adelaide 2. Flinders Diamonds Ltd,, Norwood SA 5067
}

In South Australia (SA), kimberlites are reported north of Adelaide, intruding the Late Neoproterozoic to Early Palaeozoic Adelaide Fold Belt (AFB) and from the Gawler Craton further west (Fig. 1). In the AFB these kimberlites occur as swarms of numerous, relatively thin (0.5-3 m) dykes and sills as well as rarer diatremes or pipes up to $\sim 1$ hectare.

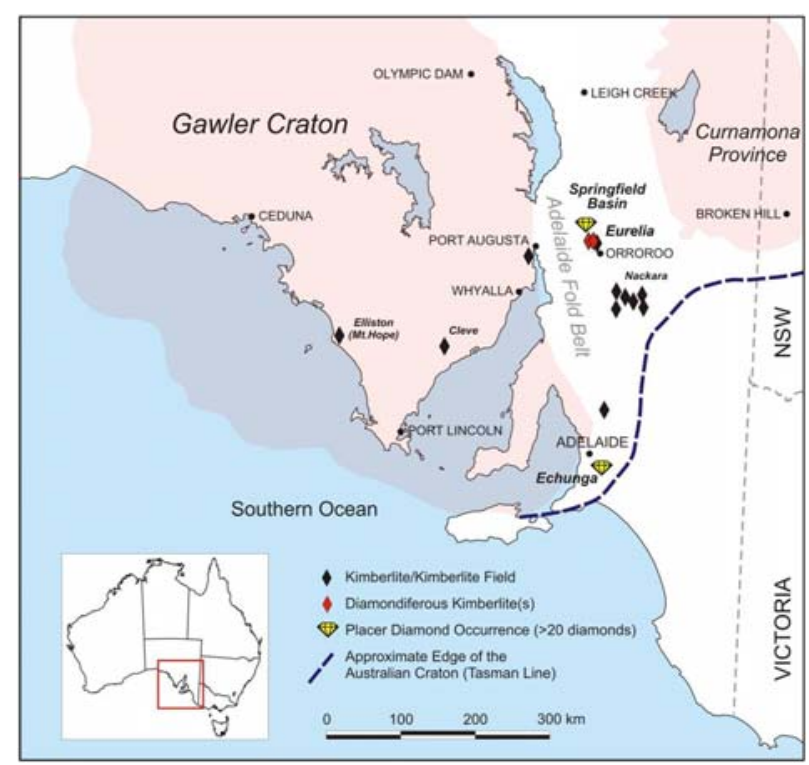

Fig. 1 Location of kimberlite dyke swarms in the Adelaide Fold Belt, north of Adelaide, South Australia

There is limited geochronology on these rocks but the kimberlite intrusions are considered Jurassic ( 170180Ma) (Black et al., 1993), though because some alluvial diamonds are reported from local PermoTriassic fluvial sedimentary deposits, there may also be so-far unidentified Triassic or Permian kimberlites (Wills, 1995; Gaul et al., 2003).

The intrusion of these kimberlites correlates with Gondwanan break-up and with probable plume activity that resulted in the Karoo-Ferrar-Tasmanian flood tholeiite sequences (Molzahn et al, 1996; Riley et al., 2006). This Jurassic, low-Ti tholeiite province (Fig. 2) extended as far north as Kangaroo island in southern SA and the zone of Jurassic kimberlite appears to lie directly beyond the periphery of the voluminously melted mantle zone (plume-head or major asthenosphere upwelling zone?) that produced the low Ti-tholeiite melts. This zone of Jurassic tholeiites extended parallel to the Pacific-facing margin of prebreak-up Gondwana, from the Karoo in southern Africa, through the Antarctic Ferrar to Tasmania and South Australia. The kimberlites in the Adelaide Fold Belt intrude Neoproterozoic sedimentary sequences deposited on the passive Rodinian break up margin and can be considered "off”- or "marginal” craton.

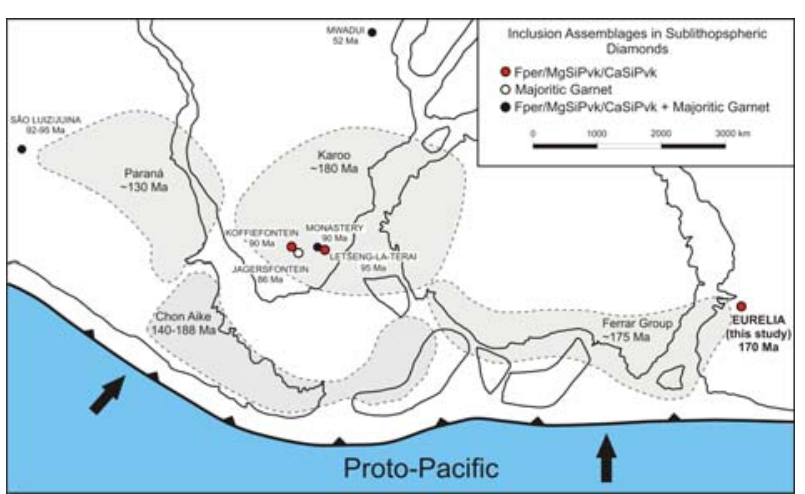

Fig. 2 Jurassic Pacific margin of Gondwanaland and the Low-Ti tholeiite provinces and kimberlites

The South Australian kimberlites are deeply weathered and as a result geochemical characterisation is imperfect. They have (weathered) olivine and variable abundance of phlogopite phenocrysts, and groundmass that includes calcite, phologopite and perovskite. Carbonate (mostly calcite) content is very variable and the data set appears to show geochemical trends that result from the separation and variable unmixing of a carbonate fluid and silicate-dominant kimberlite liquid. It is however possible to show that the most primitive, 
carbonate-poor samples have a range of trace element and Nd-isotopic characteristics that suggest they are very like South African Group I kimberlites. Their REE and mantle-normalised trace elements have all the hallmarks of Group I kimberlite (e.g. Becker and Le Reox, 2006), with steep LREE-enriched and HREEdepleted patterns (Fig.3) (La at $\sim 900 \mathrm{x}$ chondrite and $\mathrm{Yb}$ at $\sim 5 \mathrm{x}$ chondrite). Like the South African Group 1 suite, their trace element patterns are OIB-like, having marked negative K-anomalies and lacking relative Nbdepletion (Fig 4). Like Group I kimberlites they have $\mathrm{La} / \mathrm{Nb}<1.1, \mathrm{Ba} / \mathrm{Nb}$ mostly $<11.5$ and $\mathrm{Th} / \mathrm{Nb}<0.135$.

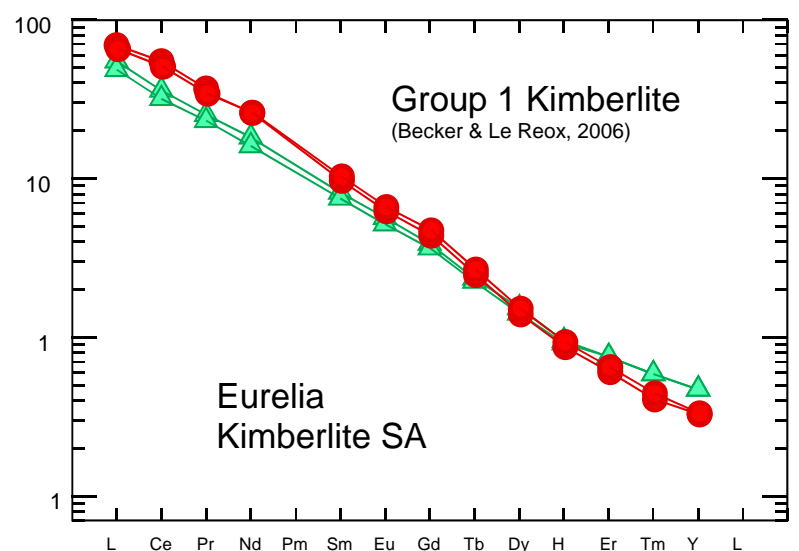

Fig.3 Chondrite-normalised Rare Earth Element patterns of South Australian kimberlite from Eurelia compared to South African Group I kimberlite

They have transported a range of mantle-derived xenoliths and xenocrysts including; lithospheric mantle peridotite (garnet lherzolite), 15-22 kbar eclogite, lower crustal granulitic and gneissic xenoliths as well xenocrysts that include; garnet, picro-ilmenite, Crspinel, Cr-diopside and diamond. Our geothermobarometry indicates the peridotitic xenocrysts and xenoliths are samples of a moderately thick (150$200 \mathrm{~km}$ ) lithospheric mantle, suggesting that though the Adelaide Fold Belt kimberlites may be off-craton, this Rodinian break-up margin must be underlain by some domains of thicker sub-cratonic lithospheric mantle. This is in contrast to the quite thin lithospheric mantle (spinel lherzolite) further east beneath the Lachlan Fold Belt (Victoria and S. NSW).

Although much of the xenocryst and xenolith population of the kimberlites is clearly of sub continental lithospheric mantle origin, some of their diamonds have inclusions (ferropericlase, MgSiperovskite) that must have very high pressure origin perhaps from below the transition zone (Scott-Smith et al., 1984; Tappert et al., 2008 submitted).

The AFB kimberlites also show some trace element similarities to local occurrences of the rift-related early Cambrian alkaline Truro volcanics (Foden et al, 2002). These are on the same temporal trend of $\mathrm{Nd}$ isotope variation as the Jurassic kimberlite, both having late
Neoproterozoic (Adelaidean) depleted mantle $\mathrm{Nd}$ model ages of $750 \pm 50 \mathrm{Ma}$ (Fig. 5). This also appears to be the approximate age of lithospheric mantle enrichment recorded for lherzolite xenoliths in Cainozoic basalts from Victoria (Griffin et al., 1988; Handler et al., 1997). This has led to the suggestion that mantle enrichment creating the kimberlite source resulted from plume and rift processes in the Rodinian break-up margin in the latest Proterozoic and Early Cambrian and implies a lithospheric mantle origin for the kimberlite (Foden et al., 2002).

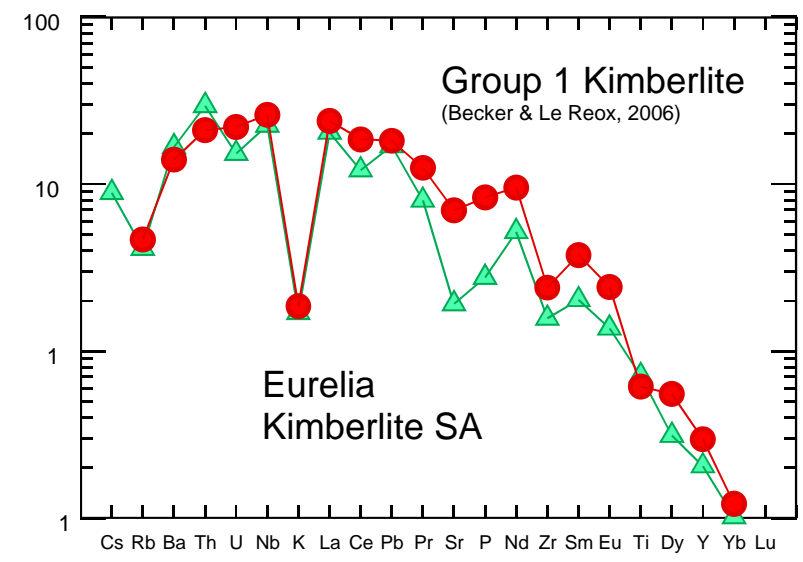

Fig.4 Primitive mantle-normalised trace element patterns of South Australian kimberlite from Eurelia compared to South African Group I kimberlite

This is consistent with the source of some diamonds and many of the xenoliths and xenocrysts in the kimberlite, but is clearly not consistent with the origin and transport of the clearly deep diamond population which require transport by kimberlite originating in the asthenosphere. This may indicate more than one source to these kimberlite magmas (SCLM and sub Transition Zone) perhaps with the capture and temporary storage of deep diamonds in the SCLM?

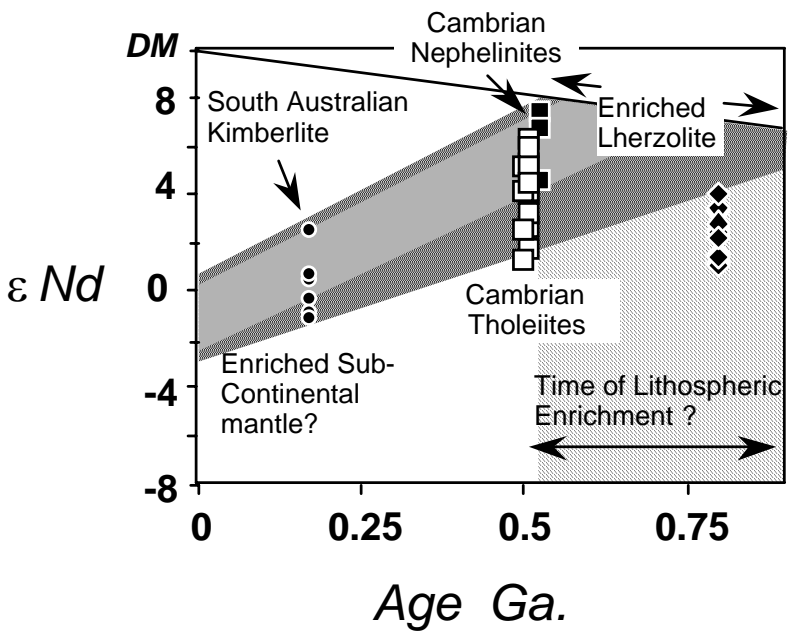

Fig.5. The Nd-isotopic composition of South Australian Jurassic kimberlite, showing the temporal evolution of the source of South Australia Cambrian nephelinites (Foden et al. 2002) and of enriched lherzolite from Victorian Cainozoic basalts (Griffin et al., 1988) 


\section{References.}

Becker, M., Le Roex, A. 2006. Geochemistry of South African On- and Off- craton , Group I and Group II kimberlites: Petrogenesis and Source Region Evolution. Journal of Petrology, 47, 673-703.

Black, L.P., Ferguson, J. and Gray, P.T. 1993. A Jurassic U$\mathrm{Pb}$ zircon age for a South Australian kimberlitic rock. Quarterly Notes of South Australian Dept. Mines and Energy, 125, 2-5

Foden, J., Song, S-H, Turner, S., Elburg, M., Smith, P., Van der Steldt, B. \& Van Penglis (2002). Geochemical evolution of lithospheric mantle beneath S.E. South Australia. Chemical Geology, 182, 663-695

Gaul, O.F., O’Reilly, S.Y. and Griffin, W.L. 2003. Lithosphere structure and evolution in southeastern Australia. Geological Society Australia. Special Pubublication. 22, 185-202

Griffin,W.L., O'Reilly,S. \& Stable, A. 1988. Mantle metasomatism beneath western Victoria, Austrlia II: isotopic geochemistry of Cr-diopside lherzolites and Al-augite pyroxenites. Geochimca Cosmochimca Acta., 52, 449-459.

Handler,M.R., Bennett,V.C. ， Esat, T.M, 1997. The persistence of off-cratonic lithospheric mantle: Os isotopic systematics of variably metasomatised southeast Australian xenoliths. Earth and Planetary. Science Letters. , 151, 61-75

Molzahn, M., Reisberg, L. \& Wo“rner, G. (1996). Os, Sr, Nd, $\mathrm{Pb}$ and isotope and trace element data from the Ferrar flood basalts, Antarctica: evidence for an enriched subcontinental lithospheric source. Earth and Planetary Science Letters 144, 529-546.

Riley, T.R., Curtis, M.L., Leat, P.T., Watkeys, M.K., 2006 Overlap of Karoo and Ferrar Magma Types in KwaZulu-Natal, South Africa. Journal of Petrology , 47, 541-566

Scott-Smith, B.H., Danchin, R.V., Harris, J.W. and Stracke, K.J., 1984. Kimberlites near Orroroo, South Autralia. In j. Kornprobst (ed) Kimberlites I. Elsevier, Amsterdam, 121-142

Tappert, R., Foden, J., Muehlenbachs, K., Stachel, T. Goryniuk, M. And Wills, K. 2008. The Diamonds of South Australia. This volume.

Wills, K.J.A., 1995. Diamond potential of the Springfield area. Report commissioned by the Springfield resources Syndicate. 